\title{
Geçmişlerinin Gölgesinde Gelin Kayınvalidenin Bakım Ilişkisi; Yaşlı İhmal ve İstismarı
}

\author{
Aslı Aydemir \\ İstanbul Üniversitesi, Sosyal Bilimler Enstitüsü, Psikoloji \\ E-Posta: aydemir.asli@hotmail.com
}

Geliş Tarihi: 16 Şubat 2021; Kabul Tarihi: 13 Mayıs 2021

Doi: 10.24876/senex.2021.36

Künye: Aydemir, A. (2021). Geçmişlerinin Gölgesinde Gelin Kayınvalidenin Bakım İlişkisi; Yaşlı İhmal ve İstismarı. Senex: Yaşlıık

Çalışmaları Dergisi, 5(1), 4-18.

(1) 0000-0002-2182-1516

\section{Özet}

Gelinler, yaşıyı ihmal/istismar eden aile üyelerinin başında gelmektedir. Gelin-kayınvalide ilişkisi kayınvalidenin yaşlanması ve gelinin bakımdan sorumlu tutulmasıyla bakım ilişkisine dönüşmektedir. Bu çalışmada bakım ilişkisi içeren altı gelin-kayınvalide çiftiyle görüşmeler yapılarak geçmiş ilişkilerinin mevcut ilişkilerine ve bakıma nasıl etki ettiği, ilişkilerini belirleyen dinamiklerin neler olduğu ile yaşlı ihmal/istismarı sonucu doğurup doğurmadığı araştırılmıştır.

Kadın olmak, oğul/eşin varlığı gelinlere bakım verme sorumluluğu yüklemektedir. Başka bir alternatifin olmadığına dair inançları, bakım vermeye rıza göstermelerine sebep olmaktadır. Kadınların akraba ilişkilerini düzenleme rolü, kayınvalideyle aynı evde yaşamak, ev içi iş bölümü, bakımla değişen konumlar gelin-kayınvalide ilişkisinde belirleyicidir. Geçmiş ilişkilerinin çatışmalı olduğunu bildiren üç gelin-kayınvalide çifti de dâhil tüm çiftler şu anki ilişkilerinden memnuniyet bildirmişlerdir ancak üç çiftte yaşlı ihmal/istismarı bulgusuna rastlanmış ya da şüphesi tespit edilmiştir. Bakımda yaşı ihmal/istismarının gerçekleşmesi gelin-kayınvalide ilişkisinin kendisine içkin olmaktan ziyade ilişkideki koruyucu dinamiklerin az, risk teşkil edenlerinse daha fazla olmasıyla ilişkilidir.

\section{Anahtar Kelimeler:}

Çatışmalı ilișkiler • Koruyucu Faktörler • Risk Faktörleri

\section{Daughter In-Law and Mother In-Law Care Relationships in the Shadows of Their Past: Elder Abuse and Neglect}

\section{Abstract}

Among the family members, daughters-in-law are the ones who abuse and neglect the older adult most. Daughtersin-law are seen as responsible for the care of mothers-in-law when they get older, so the relationship between the two turns into a relationship of care. In this study, I conducted interviews with six pairs of daughters-in-law and mothers-in-law that are in a caring relationship, and I investigated the effects of their past relationship on the present situation and the care provided, the dynamics that determine their relationship and whether those result in abuse and neglect of the older adults.

Being a woman and a wife necessitates a caregiving responsibility on daughters-in-law. Their belief that there is no alternative leads them to give consent to care. The role of women in arranging the relations of relatives, living in the same house with mother-in-law, domestic work sharing, and the changing positions with care are determinant in the daughter-in-law-mother-in-law relationship. All pairs stated that they are satisfied with their current relationships, but in three pair's relationships abuse and neglect of the older adults were identified or suspected. Rather than being immanent, the elder abuse and neglect in care is related to the fact that the daughter-in-law-mother-in-law relationship has fewer protective dynamics and more of those that pose risks.

\section{Keywords:}




\section{Arka Plan}

Yaşlı ihmal/istismarı temelde, yaşlının sıkıntı duymasına ve zarar görmesine neden olan davranış veya uygun davranış eksikliğini kapsamaktadır. Yaşlı istismarı fiziksel, psikolojik, ekonomik ve cinsel istismar türlerini içerir (Artan, 2013a). Vurmak, tokatlamak, yakmak, bağlamak, fazla ya da yanlış ilaç vermek gibi yaralayıcı ve fiziksel acı veren davranışlar fiziksel istismar; bağırmak, hakaret etmek, korkutmak, suçlamak, göz ardı etmek ya da aşağılamak gibi duygusal ve zihinsel rahatsızlık yaratacak davranışlar psikolojik istismardır. Cinsel istismar bireyin kendi rızası olmadan herhangi bir cinsel aktiviteye zorlanmasını içerirken ekonomik istismar yasal olmayan, uygunsuz bir biçimde yaşlının parasının veya diğer mali kaynaklarının şahsi çıkarlar için kullanılmasıdır (Kıssal ve Beşer, 2009). Yaşlı inmali, bilerek veya bilmeyerek yaşlıyı yiyecek, içecek, ısınma, ilaç, tıbbi cihaz gibi temel gereksinimlerinden mahrum etmeyi ve bakım sorumluluklarını yerine getirmede isteksiz davranarak veya reddederek yaşlıya duygusal, fiziksel sıkıntı vermeyi içermektedir (Quinn ve Tomita, 1997). Yetersiz beslenme, susuz bırakılma, hijyenin ve yaşıının güvenliğinin sağlanmaması gibi günlük yaşam gereksinimlerinin görmezden gelinmesi fiziksel ihmalken (Strasser ve Fulmer, 2007) bilerek ya da bilmeyerek yaşlının izolasyon, yoksunluk, ıstırap, korku, utanç, güçsüz olduğu hislerine sahip olmasına, küçük düşürülmesine ve hakaretlere maruz kalmasına müsaade etmek psikolojik ihmalin olduğunun kanıtlarıdır.

Gelinlerin aile üyeleri içinde yaşııı daha fazla inmal/istismar ettiklerine dair Türkiye'de (Artan, 1996; 2013b), Japonya'da (Soeda ve Araki, 1999), İtalya'da (Guberman, 1999), Tayvan'da (Sandel, 2004) bulgular mevcuttur. Soeda ve Araki (1999) gelinler tarafından yaşılıarın en çok beslenme, temizlik ve hastaneye gitme gibi sağlık ihtiyaçlarını karşılamayarak ihmal edildiğini bulgulamışlardır. Yanı sıra gelinler görmezden gelme, azarlama, küfretme, sıklıkla "ölsen daha iyi" deme ve telefonu kullandırtmama gibi eylemlerle psikolojik istismarda bulunmaktadırlar. Gelinlerin çatışma çözümü olarak kullandıkları stratejiler yaşı ihmalini içerebilmektedir. Şöyle ki Marotz-Baden ve Cowan'ın (1987) çalışmasında gelinler aralarındaki çatışmayı çözmek için en çok kullandıkları stratejinin kayınvalidelerini görmezden gelmek olduğunu bildirmişlerdir ve görmezden gelme yaşlı ihmal davranışlarındandır.

Soedave Araki'nin (1999) çalışmasında gelinler yaşlıyı ihmal/istismar etmelerinin ilk sebebi olarakkayınvalideya da kayınpederleriylekötü ilişkiye sahip olmalarını ve ikinci sebep olarak bakım stresini dile getirmişlerdir. Kayınvalide ve kayınpederleriyle kötü ilişkilerinin başat sebebi, gelinlerin yakınlık duymadıkları bu aile üyeleriyle birlikte yaşamaları, kuşak farklılığı sebebiyle farklı his ve görüşlere sahip olmaları ve otorite sahibi yaşı ıadının ev içi iş bölümünde karar verici olması gibi ilişkisel dinamiklerdir. İkinci sebep eş/oğulun gelin-kayınvalide ilişkisi içinde arabulucu olmaması ve hem ev işlerinin yürütülmesinde hem de bakım verme sırasında eşlerine yardımcı olmamasıdır. Üçüncü sebep ise kayınvalidelerin sadece, ailelerini yönetmek üzere yetiştirdikleri oğullarına saygı duymaları ve gelinlerinden oğullarına itaat beklemeleri, oğullarının ailesine çok müdahil olmalarıdır. Ayrıca istismar eden gelinler eşlerinin anne babalarına bakmak istemediklerini, kendilerinin bakmak zorunda bırakılmalarını adil bulmadıklarını bildirmişlerdir. $\mathrm{Bu}$ hislerin yoğunluğunun artmasına sebep olarak eşlerinden yeteri kadar destek görmemelerini ifade etmişlerdir. Yanı sıra gelinlerin bakım emeklerine aile üyeleri ve profesyoneller tarafından çok az dikkat edildiği ve eylemlerinin kötülendiği; gelinlerin yaşının parasını bekledikleri ve yaşılıara kötü davrandıkları gibi önyargılara maruz kaldıkları da görülmektedir (Guberman, 1999). 


\section{Amaç}

Bu çalışmanın amacı, çatışmalı bir ilişki ön kabulüne sahip gelin-kayınvalide ilişkisini yaşlılık ve bakım gereksinimi kesişiminde derinlemesine incelemektir. Artık gelinlerin bakım veren, kayınvalidelerin bakım alan olduğu gelin-kayınvalide çiftlerinde, geçmiş ilişkilerinin mevcut ilişkilerine ve bakıma nasıl etki ettiği, ilişkilerini belirleyen dinamiklerin neler olduğu ile yaşlı ihmal/istismarı sonucu doğurup doğurmadığını araştırmaktır.

\section{Yöntem}

Araştırma sorusunun bir gereği olarak bu çalışma gelin-kayınvalide ilişkisi, bakım ilişkisi ve bakım sırasında ortaya çıkabilecek yaşlı ihmal/istismarının birlikte ele alındığı bir işbirlikli durum çalışmasıdır. İşbirlikli durum çalışması birkaç durumun bir arada ele alınmasını mümkün kılarak insanların sosyal davranışlarını kavramsallaştırmayı ya da özetlemeyi mümkün kılar (Glesne, 2014). Aynı zamanda işbirlikli durum çalışması durumun karmaşıklığına, biricikliğine ve içinde bulunduğu bağlamla olan ilişkisine odaklanmayı sağlar.

\section{Prosedür}

Araştırma İstanbul Üniversitesi Sosyal ve Beşeri Bilimler Araştırmaları Etik Kurulu Başkanlığı tarafından etik yönden uygun bulunmuştur.

Yaşılı Istismarı Tanı ve Müdahale Modeli (YITAM); Yaşlı ihmal/istismarını tespit etme amacındaki bu çalışmanın yöntemsel zeminini Quinn ve Tomita'nın (1997) YiTAM'ı oluşturmuştur. YITAM teorik olmaktan ziyade, pratisyenler için yaşlı ihmal/istismarının tanı ve tedavisinde tutarlı, uyumlu prensip ve metotları sunan uygulamaya dönük bir modeldir, tanı ve müdahale olmak üzere iki aşamalıdır. Bu çalışmada yararlanılan tanı aşaması başvurunun alınmasını, değerlendirme görüşmesi için hazırlıkları ve hem yaşlı hem de bakım vereniyle ayrı görüşmelerin yürütülmesini içerir ve bu görüşmelerin birlikte ele alınmasını önerir. Dolayısıyla çalışmada bakım veren ve bakım alana yönelik sorular oluşturulmuş, yaşlı ihmal/istismarına dair bildirimler analiz aşamasında birlikte değerlendirilmiştir. Bu sorular arasında bakım alan yaşlı için bakım sırasında fiziksel olarak canını yakan, onu korkutan bir şeylerin olup olmadığı, bilmeden herhangi bir belge imzalayıp imzalamadığı, istemediği halde yalnız bırakılıp bırakılmadığı gibi sorular mevcuttur. Bakım verene ise bakım sürecinde yaşlıya zaman zaman bağırma ya da istemediği şeyler yapma gibi durumlar içinde olup olmadığı sorulmuştur. YITAM, görüşme ve değerlendirmeler sonucunda "ihmal/istismar bulgusuna rastlanmadı", "ihmal şüphesi bulunmaktadır", "istismar şüphesi vardır" ya da "ihmal/istismar bulgulanmıştır" olarak geçici tanı konabileceğini söylemektedir. Bu çalışmada YITAM'ın önerilerine göre görüşmeler gerçekleştirilmiş, görüşme sonuçları değerlendirilmiş ve geçici tanı konulmuştur.

Yarı Yapılandırılmış Görüşmeler; yaşlıların sağlık durumu sebepleriyle katılımcıların evlerinde, görüşme yapmaya uygun odalarda yaşlı ve bakım vereniyle ayrı ayrı ses kaydı alınarak yapılmıştır. illk olarak yaşlılarla ardından bakım verenleriyle görüşme yapılmıştır. Görüşmeler YiTAM'ın ihmal/ istismarın tespiti için önerdiği sorularla birlikte gelin-kayınvalide çiftinin ilişkilerinin geçmişi, bugünü ve mevcut bakım ilişkisine dair sorularla 2015 yılı Mayıs ve Haziran aylarında yürütülmüştür. Yaşlılarla yapılan görüşmeler ortalama 21, bakım verenlerle yapılan görüşmeler ortalama 58 dakika sürmüştür.

Tematik Analiz; metinde spesifik bir örüntü olarak temaların arandığı (Joffe ve Yardley, 2004) bu analiz ya önceden belirlenmiş, 
geliştirilmiş kategoriler (kapalı yaklaşım) kullanılarak ya da bu yapılamadığında veya uygun olmadığında araştırmacının kendi kategori sistemini geliştirmesiyle (açık yaklaşım) mümkün olmaktadır. Bu çalışmada iki yaklaşım birlikte kullanılmıştır.

\section{Katılımcılar}

Araştırmanın katılımcıları için aranan tek koşul evde bakım veren gelin ve gelininden bakım alan kayınvalide çifti olmalarıdır. Bu bakım ilişkisine sahip olan katılımcılara yerel belediyelerin evde sağlık hizmetleri kapsamında ulaşılmıştır. Bilgilendirilmiş onam formuyla onayı alınmış 6 gelinkayınvalide çiftiyle araştırma yürütülmüştür. Gelin-kayınvalide çiftinin 4'ü İstanbul'da, 2'si Kütahya'da yaşamaktadır. Gelinler 3459 yaş aralığındadır ve evlilik süreleri 2 ile 36 yıl arasındadır. Kayınvalideler 64-85 yaş aralığındadır. Katılımcıların tümü ev hanımıdır, sadece bir gelin bakım sebebiyle işini bırakmak durumunda kalmıştır. Gelinlerin tümü evlendiklerinden bu yana kayınvalideleriyle birlikte yaşamışlardır. Kayınvalidelerin 4'ü duldur, gelinlerin ise tümü evlidir. Gelinlerin 5'i ilköğretim mezunuyken biri üniversite mezunudur. Kayınvalidelerin 4'ü okuma yazma bilmezken, biri ilköğretim mezunu, bir diğeri ise okuryazardır. Analiz sırasında gelin-kayınvalide çiftleri, çift olarak numaralandırılmıştır ve bulgular çift numaralarına (birinci, ikinci çift gibi) göre aktarılmıştır.

\section{Bulgular}

Bu bölümde ilk olarak yaşlı ihmal/istismar bulgularına ardından bakıma etki eden gelinkayınvalide ilişki dinamiklerine yer verilecektir.

\section{ihmal/istismar Bulguları}

iliş̧kilerinin geçmişte çatışmalı (birinci, üçüncü ve altıncı çift) ya da çatışmasız (ikinci, dördüncü ve beşinci çift) olmasıyla beraber gelin ve kayınvalideler, hem bakım ilişkileri hem de aralarındaki mevcut ilişkiye dair memnuniyet bildirmişlerdir. Ancak görüşmeler sonucunda 6 gelin-kayınvalide çiftinden 3'ünde yaşlı ihmal/istismarı bulgusuna rastlanmış ya da şüphesi tespit edilmiştir. Gelin ve kayınvalidelerin, yaşı ihmal/istismarının olduğuna dair şüphe içeren ifadeleri karşılıklı olarak değerlendirilmiştir.

Illk çiftte kayınvalide kendisine yönelik hem psikolojik (evde yalnız bırakma) hem de fiziksel ihmal (doktora götürmeme, ilaçların temin edilmemesi, yalnız bırakılan yaşlının evde gazı açık unutması), yanı sıra psikolojik (azarlama, bağırma) ve ekonomik istismar (mal paylaşımında yaşlıya söz hakkı verilmemesi, yaşlının maaşına el konulması) bildirmiştir. Gelin ise sadece psikolojik istismar sayılan bağırma eylemini gerçekleştirdiğini ifade etmiştir. İkinci çiftte, gelin ve kayınvalidenin konuşmalarında sadece ekonomik istismarın varlığından şüphe edilmiştir. Kayınvalidenin yaşlı aylığı oğlu ve gelini tarafından kullanılmaktadır ancak kayınvalide bu durumu olağan görmekte ve istismar olarak deneyimlememektedir. Üçüncü çiftte ise gelinin bildirimlerinde psikolojik ihmalin varlığından şüphe edilmiştir. Kendi odasında kalan ve yatalak olduğu için ileri derecede bakım verenine bağımlı olan kayınvalidenin boynunda, herhangi bir şeye ihtiyaç duyduğunda çalabilmesi için bir düdük asılıdır. Kayınvalide bu düdüğü çalarak gelinin günlük yaşam pratiklerine (salonda yemek yeme, torunla vakit geçirme) dâhil olmaktadır. Bakımın gereği olarak gelin nezdinde meşrulaştırılan düdük, aynı zamanda kayınvalidenin odasında yalnız kaldığının bir göstergesidir. Ancak kayınvalide herhangi bir ihmal ya da istismar bildirmemiştir.

Ilk gelin-kayınvalide çiftinde hem gelin hem de kayınvalide ilişkilerine dair bir çatışma algılamadıklarını bildirseler de görüşmeler boyunca çatıştıkları durumları aktarmışlardır. Gelin, geçmiş ilişkileri sebebiyle 
kayınvalidesine kızgındır. Bu kızgınlık kayınvalidesinin kendi ailesine yönelik tavır ve tutumlarında belirgindir. Gelini için, kayınvalidesinin otoriter olması, hatır gönül bilmemesi, gelinin eylemlerine müdahale etmesi ve uyumsuz davranışlarda bulunması çatışmalı ilişkilerine sebeptir. Önceki araştırmalarda da görüldüğü üzere yaşlının çok konuşması ve her şeye karışması bakım sırasındayaşanan ve bakım vermeyizorlaştıran iletişim güçlüklerindendir (Alpteker, 2008; Bilgili, 2000). Tüm bunlara rağmen gelinin bakım veriyor olması, kendi niyeti dışında içinde bulunduğu zorunlulukların bir sonucudur. Bu zorunluluklar bakacak başka kimsenin olmayışı ve eşinin varlığıdır. Kendisini güdüleyen bir diğer etken, dinî inancıdır. Bakım sırasında kayınvalidesinin beklentileri yerine, kendi davranışlarının sevap olup olmadığını gözetmektedir. Gelinin zorunlu bakım vermesi ve geçmiş çatışmaların kızgınlıklarını hâlâ duyması gelini kayınvalidenin talep ve sorunlarına duyarsız kılmıştır. Kayınvalide 83 yaşındadır ve ölüm sebebiyle sosyal ilişki ağında ciddi daralma bildirmektedir. Yakınlarının yaşlının sorunlarıly ilgilenmemesi, sosyal ilişkilerinin az olması ve yaşının fazla olması, ihmal/ istismar için risk oluşturmaktadır (Keskinoğlu vd., 2004). Bu çiftteki kayınvalideyi ihmal/ istismara karşı korunmasız kılan bir diğer etken, eş/oğulun geline bağlılığıdır. Bu bağlılık, oğulun evdeki yaşlı ihmal/istismarının farkına varamamasına sebep olabilir.

Çatışmalı ilişkileri sebebiyle yaşlı ihmal/ istismarı için risk taşıyan üçüncü ve altıncı çiftlerde kesin ihmal/istismar bulgusuna rastlanmamıştır. Her iki çiftte de yaşlıyı ihmal/ istismardan koruyan etkenler arasında, özellikle gelinlerin kendi kişilik özelliklerine yaptıkları atıflar vardır. Her iki gelin kendi aileleri tarafından kayınvalidelerine bakım vermeleri için tembihlendiklerini, cesaretlendirildiklerini ve ailelerinin kendilerine destek olduğunu bildirmişlerdir. Çatışmalı geçmişleri dolayısıyla bu gelinlerin kayınvalideleriyle ortak aile aidiyeti duymaları zor olmuştur. Üçüncü gelinin eşi, annesine bağlılı̆ı sebebiyle çatışma ortamını sürdürmüş, kayınvalide torunu aracılığıyla gelini üzerinde tahakküm kurmuş ve gelinin ailesine yönelik tavırları sebebiyle gelininin ortak aile aidiyeti duymasının önüne geçmiştir. Eşiyle ilişkilerinin başlarında istenmeyen altıncı gelin, kayınvalidesi ve kayınpederine sağladığı bakım aracılığıyla aileye dâhil olabilmiştir. Altıncı gelin çatışma ortamında kalmayı ve bakım vermeyi sürdürmesini eşine duyduğu sevgiyle açıklamıştır.

Çatışma bildirmeyen ve ilişkilerinden memnun olduklarını dile getiren ikinci, dördüncü ve beşinci çiftlerin ise kendi gelinkayınvalide ilişkileri içinde farklı dinamikleri vardır. Beşinci gelin-kayınvalide çiftinin arasındaki bakım ilişkisine özellikle etki eden, doğumundan bu yana bakım verilen engelli bir oğul/torunun varlığıdır. Engelli oğlu nedeniyle bakımın gündelik pratik olarak hayatında yer etmesi, gelinin bakım yükü algılamamasına sebep olmuştur. Aldığı sosyal desteklerle beraber sosyal yaşantısında kısıtlılık hissetmemesi bakım ilişkisinden memnuniyet duymasını sağlamıştır. Beşinci gelinin duyduğu memnuniyetin bir sebebi, kayınvalidelere yönelik olumsuz atıfların kendi ilişkisinde yer almamasıdır. ilişkisel memnuniyetin bir sonucu olarak, gelin bakım verdiği kayınvalidesiyle empatik biçimde ilişkisini sürdürmektedir ve kayınvalidesinin perspektifiyle, onun beklenti ve özelliklerini gözeterek bakım sağlamaktadır. Bunun yanı sıra kayınvalidesi, kendisiyle uyumlu bakım taleplerinde bulunmaktadır ve bu durum bakım yükü algılanmasının önüne geçmektedir.

İkinci gelin, kayınvalidesiyle ortak aile aidiyeti duyduğunu, kayınvalidesiyle arkadaş gibi olduklarını belirtmiş ve kayınvalidesinin kendisiyle uyumlu bakım taleplerinde bulunduğunu söylemiştir. Bu çiftte, eş/ oğulun ilişkilerine verdiği destek, şüphe 
duyulan ekonomik istismar dışında diğer ihmal/istismar türlerinin yaşanmasının önüne geçmiştir. Hatta gelin bakım ilişkisinden duyduğu memnuniyetin yanında kayınvalidesinin varlığından memnundur ve yakında doğacak çocuğunun bakımı için destek beklemektedir. Dördüncü gelinkayınvalide çiftinde ise bakımı zorunlu kılan eş/oğulun varlığı, bu ilişki dinamikleri içinde farklı işlemektedir. Şöyle ki eş/ oğul, 15 yıldır yurtdışında olması sebebiyle yanlarında değildir, yoktur ancak engelli çocuklarına verdiği bakımın yüküyle birlikte "yetemediğini" söylese bile kayınvalide ve kayınpedere verilen bakım gelin tarafından sürdürülmektedir. Buradaki önemli etken, gelinin vurguladığı üzere evlilikle kurulan ilişkilerin hak, görevve sorumluluklarıdır. Evlilik kurumu, kocanın ailesinin sorumluluklarının gelin tarafından alınmasını gerektirir ve kayınvalideyle kayınpederin bakımını garantileyen bir sözleşme içermektedir. Gelin bakım vermesini bu sözleşmenin kendisini yükümlü kılması, vicdani sorumluluk ve "tez canlı, aileci biri ve güçlü bir kadın" olması gibi kendi kişilik özellikleriyle açıklamıştır.

\section{Bakıma Etki Eden Illişki Dinamikleri}

\section{Bakımın Garantisi Oğul}

$\mathrm{Bu}$ çalışmadaki tüm gelin-kayınvalide çiftlerinde gelinlerin bakım vermesinin asıl sebebi kocalarıdır. Türkiye'de yaşlı aile üyesinin bakımından oğul ve eşi sorumlu tutulmaktadır. Gelin ve kayınvalideler, görüşmeler sırasında neden oğul ve eşinin bakım vermesi gerektiğini tartışmışlardır. Elkızları gelinler, kayınvalidelerinin kızlarının evlenip "gitmiş" olması ve damadın "yabancı" olması sebebiyle bakımdan oğul ve kendilerini sorumlu tutmuşlardır. Kayınvalideler oğulları varken damatları nedeniyle kızlarının yanında kalmayı tercih etmeyeceklerini söylemişlerdir. Bilgili'nin (2000) çalışmasında, yaşlandıklarında kızlarının yanında kalmanın çevrelerince ayıplanacağı ve damatların yanında rahat edemeyecekleri bildirilmiştir. Bu çalışmada damadın karşı cinste bir yabancı olması, kayınvalidelerin onların yanında rahat olmayacağına sebep olarak aktarılmıştır ancak bunun aksine gelinler, karşı cinsteki kayınpederlerinin de bakımını üstlenmişlerdir. Aşağıda altıncı kayınvalidenin betimlediği gibi, evlendikten sonra kızlarının evi onlar için, içinde rahat edemeyecekleri damat kapısıdır.

"Oğlum dururken damadın kapısında ne edecem ki diyorlar damattan oğul olur gelinden kız doğru da yine de oğlum varken ben niye gideyim damadın evine...oğul başka (K6)"

Ikinci kayınvalide oğlu gibi gelininin de evladı olduğunu ve bu nedenle kendisine bakım vermeye mecbur olduğunu söylerken, geliniyle çatışmalı bir ilişkisi olan ve ihmal/ istismar edilen birinci kayınvalide oğlunun varlığı sebebiyle gelininin bakım verme zorunluluğu olduğunu belirtmiştir. Gelinler birinci gelinin ifadesinde görüldüğü gibi bu zorunluluğu dinî sebeplerle de kabul etmişlerdir.

\section{"Gocamın annesi mecbur una}

bakasan bu dünyada geçiciyiz gızım mükafatını öbür âlemde alcen (G1)"

Oğullar gelinler tarafından sevildikleri için de bakımın garantisi olmaktadır. Gelinlerin eşlerine duydukları bağlılık, zorunluluk ya da sorumluluk hissi, onları bakım vermeye zorlamaktadır (Globerman, 1996). Kadınların bakım vermesi, kendi iradeleri dışında oğul ya da damadın varlığı ve sadece kadın olmalarıyla gerçekleşmektedir.

\section{Kadınlık}

Aile üyeleri arasında bakımı üstlenen kadınlar daha çok eş, kız evlat ya da gelinlerdir ve gelinler çoğunluğu oluştururlar (Louderback, 2000). Geçmişte kendi kayınvalidelerine 
baktıklarını söyleyen kayınvalideler, kendi bakımlarından gelinlerini sorumlu tutarak yaşlı bakımında kadının bakım emeğini olağanlaştırmaktadır. Çalışmalar özellikle köylü kadınların hizmet eden genç kız ve gelin konumundan, hizmet edilen hatta ezen kayınvalide konumuna doğru yol aldıklarını bulgulamışlardır (Sirman, 2010). Kadınlar yaptıkları pazarlıklar sonucunda oğullarıyla uzlaşarak bu değişimi (Kandiyoti, 1988) ve dolayısıyla yaşlandıklarında alacakları bakımı garantilemişlerdir.

Bakımın üstlenilmesinde ya da bakım verirken desteğe ihtiyaç duyduklarında tüm gelin ve kayınvalidelerin akıllarına elti, görümce, gelinlerin kendi kızları gibi ailenin diğer kadın üyeleri gelmiştir. Kadınlar bakım vermede kendilerini eşleriyle değil, diğer kadınlarla karşılaştırmakta ve bakım vermenin kadınların işi olduğu kabulü sonucunda eşlerinden düşük beklenti içinde olup bakıma kendilerinin çok, eşlerinin az dâhil olmasına sebep olmaktadır (Thompson, 1991). Bu çalışmada kayınvalide ve gelinlere oğul/eşlerinin destek olup olmadığı sorulduğunda, tümü toplumsal cinsiyet rolleri içinde erkeğe düşen görevlerin gerçekleştirilmesini bakıma destek olarak belirtmişlerdir. Kadın ve erkekler arasında kesin, katı iş bölümünün kabulü birinci gelin ve kayınvalidenin ifadelerinde görülmektedir:

"Oğlan getiryo gelin pişiryo yiyoz aldığı paranan (K1)"

"Biz unun getirdini yioz işte her şeyi bol bol alveri (G1)."

Eşlerinin bakıma destek olduğunu söyleyen gelinler aldıkları destekler arasında odun, kömür getirme, sofrayı taşımaya yardım etme, çöp atma gibi ev içi işlerdeki küçük yardımları ve eşlerinin karınlarını kendi başlarına doyurmalarını dile getirmişlerdir. Yani, eşlerin toplumsal cinsiyet rollerinin gerektirdiği kadarını yapmaları destek kabul edilmekte, fazlası beklenmemekte ve talep edilmemektedir. Brewer (2001) ve Guberman'ın (1999) belirttiği gibi, katı cinsiyetçi iş bölümü ve bu iş bölümü sebebiyle erkeğin bakım kapasitesi olmadığı kabulü, bakım alanla verenin cinsiyetinin farklı ya da aynı olması, bakımda sorumluluğun paylaşılmasında ya da tamamen üstlenilmesinde belirleyicidir. Kadınlar toplumsal cinsiyet rollerini kabullenmekte, bakımı kadınlardan beklemekte ve erkeklerin sağlayacağı bakımın nitelikli olmayacağını düşünmektedir (Gönüllü Taşkesen, 2012).

Toplumsal cinsiyet rollerinin böylesine kabulü, haliyle bakım sırasında desteğe ihtiyaç duyulduğunda akla diğer kadınlara başvurmayı getirmektedir. Gelinlerle niye onların bakım verdiği konuşulduğunda, değerlendirmeleri diğer kadın aile üyeleri üzerinden olmuştur.

"Mecburiyetten bi de yok bende merhamet çok var. Allah rızası için çok benim eltim de olsaydı görümcem de olsaydı tek çocuk çünkü benim eşim .... onun hiç kız evladı yok (G3)"

Yukarıdaki ifadede görüldüğü gibi üçüncü gelin, tek oğlu olan kayınvalidesine bakım vermeyi sürdürmesini mecburiyet, kişilik özelliği yanında ailenin aslında var olmayan diğer kadın üyeleriyle açıklamıştır. Bununla birlikte üçüncü gelin bakım için oğlu da varken kızından destek istemektedir, çünkü bakım alt değiştirmeyi içermektedir ve karşı cins bunu yapmaya uygun değildir. Birinci gelin ise en azından yurt dışından geldiğinde kısa bir sürede olsa eltisinden bakım yükünü üzerinden almasını istemektedir.

Nihayetinde bu çalışmanın katılımcıları için genel kabul, bakım vermenin kadın işi olduğudur. Bu kabul, kız evlatları oğullara göre birincil bakım vermeye daha istekli yapmaktadır. Oğullar bakımın garantisidir ancak bakım vermekten sorumlu değildir. 


\section{Akraba ilişkilerinden Sorumlu Kadın}

Kadınların üstlenmek durumunda kaldıkları akraba ilişkilerini düzenleme rolü, gelin ve kayınvalideler arasında çatışma yarattığı gibi, kayınvalideye bakım verilmesini içermektedir. Böylelikle gelin, kocasının akraba ilişkilerini düzenlemiş olmaktadır (Globerman, 1996). Gelinin hem eşinin hem kendi ailesinin üyeleriyle ilişkisinin nasıl olduğu ve bu ilişkilere kayınvalidenin ne şekilde etkide bulunduğu, bu rolün gelindeki yükünü ve bakımın niteliğini belirlemektedir.

Kayınpederle ilişki, dördüncü gelinkayınvalide ilişkisini zora sokarken üçüncü çiftte ilişkilerine destek olmaktadır. Altıncı gelinin görümceleriyle yaşadığı gerilim, kayınvalidesiyle hem kocasının hem kendisinin çatışmasına sebep olmuştur. Yaşlı inmal/istismarının tespit edildiği birinci çiftte ve psikolojik ihmalden şüphelenilen üçüncü çiftte gelinler, kayınvalidelerinin kendi ailelerine yönelik olumsuz tavırve tutumlarının olduğunu ve bu sebeple çatıştıklarını belirtmişlerdir. Altıncı gelin, "kadının özverisi ile ilişkilerin sürdügüunü" belirtirken aşağıda birinci gelinin ifadelerinde kadının düzen kurucu, ilişkileri koruyan rolü görülmektedir.

"Torun bu apartmanı ayakta tutan varsa her şesini organize eden varsa sensin deyo ben işte bi evden gitvedim mi geldim mi bin bir şikayet olur u undan şikayet ede gızz noldu bakam bi gün gittim evden (G1)"

\section{Alternatif Olmadığına Inanç ve Rıza}

Gelinlerin bakım veren olmaları, bakım vermenin getirdiği sorumluluklar nedeniyle fiziksel, psikolojik, sosyal değişimleri içermektedir. Bu değişimler kayınvalidenin bağımlılık durumuyla ve algılanan bakım yüküyle ilişkilidir. Gelinler bakım sürecinde yorgunluk, sinirlilik, huzursuzluk, üzüntü, yetersizlik hissi ve bakım sebebiyle sosyal yaşantılarında kısıtlılık bildirmişlerdir. Sosyal yaşantılarındaki kısıtlılıklar içinde sosyal ilişkilerinde daralma, mevcut işlerini bırakma, çalışamama, evden hiç çıkamama, kendileri için zaman ayıramama gibi durumlar yer almaktadır. Evden çıkamamanın yarattığı kilo alımı, tam bağımlı kayınvalidelerin taşınması sebebiyle bel fıtığı gelinlerin bildirdikleri fiziksel sonuçlardır. Bunlarla birlikte çamaşırları makinada iki kez yıkama, tuvaleti özellikle kayınvalidesi götürülmüşse ardından bir şişe çamaşır suyuyla yıkama, her gün kayınvalidesinin yastık kılıfını çıkarma ve uzun saatler mutfağın temizlenmesi gibi kompulsif davranışların olduğu görülmüştür. Bunlarla birlikte gelinlerin başvurdukları baş etme stratejileri kabul etme, olumlu yönüyle bakma, dua etme, çatışmanın olduğu ortamdan kaçınma, ağlama hatta kendi odalarında duvara vurma gibi duygularını dişa vurmaya yönelik pasif stratejilerdir. Bakım sırasında karşılaşılan problemi, stres kaynağını çözmeye yönelik tek aktif başa çıkma stratejisi, ihmal/istismar edilen yaşlının bakım parası talebinin olmasıdır. Birinci kayınvalide aşağıdaki ifadesiyle yaşlıya verilen bakımda devletin ve sosyal politikaların etkinliğine atıfta bulunan tek katılımcıdır.

\section{"Hökümet bana bişe der mi (K1)"}

Yukarıdaki tüm zorluklarına rağmen bakım vermeye mecbur kılan bir diğer etken, bakacak başka kimse ya da kurumların yokluğudur. Bakım veren kadınların başka alternatiflerin olmadığına dair inançları, onları aile üyelerine bakım vermeye mecbur bırakmakta ve sosyal ya da kurumsal destek taleplerini engellemektedir. Engelli çocuğu olan beşinci gelinin aşağıdaki ifadesinde bu inancın zorunlu sonucu olarak kabulü dile getirişi görülmektedir.

"Alışkınlık oldum sonuçta bu bakıma muhtaç o da zaten bakıma muhtaç yapılcak bişiy yok hayat bi şekilde devam ediyo (G5)"

Kadın olmalarının onları bakıma zorunlu 
kıldığı toplumsal düzende gelinler, destek ya da başka bir yol için alternatif olmadığına dair inançları ve bakım yükü arasında sıkışıp kalmaktadırlar. Bu sıkışma hali, onları neden bakım verdiklerini bir şekilde açılamak durumunda bırakmaktadır, böylelikle bu hal sürdürülebilir olacaktır. Çatışma yaşadığı kayınvalidesine bakım veren üçüncü gelinin aşağıdaki ifadesi bu açıklamalardan biridir.

"Rabbim bunu bana yakıştırmış (G3)"

Bu açıklama gelini, içinde bulunduğu konumla çatışmaktan korumaktadır; çünkü bakım vermesi, ilahi bir güç tarafından kendisine biçilmiştir ve ilahi olana karşı çıkmak mümkün değildir.

"Allahtan öyle söylenmiş öyle yetiştirilmiş o da bakıyo biz zorlamıyoruz etmiyoruz kendiliğinden öyle (K6)"

Yukarıdaki ifadede ise altıncı kayınvalide gelininin bakım vermesini ilahi bir güçle açıklamaktadır. Kayınvalidenin bu açıklaması kayınvalideye, gelinini bakım vermeye kendilerinin zorlamadıklarını dile getirme imkânı vermektedir. "Öyle yetiştirilmiş" ifadesi "biz zorlamıyoruz" ifadesiyle birlikte katı iş bölümünü dayatan patriarkal düzenin yaşlı kadına sağladıklarının göstergesidir.

Gelinleri bakımı sürdürmeye ikna eden ve onları bu sıkışmış halden koruyan diğer etkenler bakım verme yüceliği, bakım veren saygısı, bakım vermede anlam bulma ve bakım vermede deneyimden kazanımdır. Verdiği bakım sebebiyle güçlendiğini belirten dördüncü gelin ve bakım vermesiyle hayatının daha anlamlı olduğunu söyleyen, komşuları, çocukları, doktorlar tarafından nitelikli bir bakım verdiği için yüceltilen üçüncü gelin, hissettikleri bakım yüküyle bu şekilde başa çıkabilmektedir. Özellikle üçüncü gelinin çatışmalı ilişkisine rağmen bakım vermesi takdir görmektedir. Devletin taraf olduğu bu sosyal uzlaşı, bakım verme zorunluluğu karşısında kadını yalnız bırakırken diğer yandan onları toplum içinde kutsamakta, yüceltmekte dolayısıyla bakımın sağlanmasını garantilemektedir. Sadece kayınvalidesini inmal/istismar eden birinci gelin ve çocuk sahibi olduğunda altıncı gelin bir başkasının, bu bir başkası yine kadındır, kayınvalidesinin bakımını üstlenmesini beklerken, diğer gelinler kayınvalidelerinin bakımlarını başkalarının üstlenmesini istemediklerini belirtmişlerdir.

\section{Aynı Evde Yaşama}

Bu çalışmadaki gelin-kayınvalide çiftleri hem ekonomik koşullar hem de yaşlılık ve bakım sebebiyle evliliğin başlangıcından bu yana aynı evde yaşamaktadırlar. Gelin-kayınvalide arasındaki iletişim sıklığı özellikle gelinin iletişime geçme isteğinin olup olmaması, ilişkilerinin bir sonucu olabileceği gibi aynı zamanda ilişkilerini belirleyici bir etkendir (Rittenourve Soliz, 2009). Ancak bu çalışmanın katılımcılarının aralarındaki iletişim, aynı evde yaşamaları sebebiyle süreklidir ve tercih etme, isteme dışında zaruridir. Aynı evde 36 yıldır yaşayan birinci gelin, görüşme boyunca çatışmalarını aktardığı kayınvalidesinin bakım sürecinde psikolojik olarak ne durumda olduğuna duyarsızdır. Otuz yıldır birlikte yaşayan beşinci gelin, çatışma yaşamadığı kayınvalidesinin yatalak olması sebebiyle bakım almasının, kayınvalidesinde yarattığı psikolojik etkilere duyarlıdır ve empatik bir biçimde, kayınvalidesinin perspektifiyle bakım sağlamaktadır. Gelin ve kayınvalidelerin aynı evde yaşamaları iletişim sıklığının niceliği üzerinde kesinkes belirleyicidir ama iletişimin niteliği gelin-kayınvalide ilişkisinin taşıdığı ilişkisel ve iletişimsel dinamiklerinin nasıl olduğunun bir sonucudur.

Aynı evde yaşama, gelinin kayınvalidesiyle ortak aile aidiyeti duymasında ilişkilerinin niteliğinden bağımsız olarak doğrudan etkilidir. Ortak aile aidiyeti duymasının önünde engel olarak diğer aile üyelerinin 
etkisi olduğunu ve dolayısıyla tam olarak aileye aidiyet hissedemediğini bildiren altıncı gelin dışında tüm gelin ve kayınvalideler uzun yıllar beraber yaşamalarına vurgu yaparak, ana-kız benzetmesi ile ortak aile aidiyeti duyduklarını ifade etmişlerdir. Aynı evde yaşama, iletişimin sürekliliğini zorunlu kılması sebebiyle herhangi bir çatışmanın sonucu olarak iletişimin kesilmesinin önüne geçmektedir. Bu durum gelinler ve kayınvalideler tarafından dile getirilmiş, "bağırıp çağırıp yerine oturma" gibi ifadelerle iletişimlerine ana-kızlar gibi kaldıkları yerden devam ettiklerini vurgulamışlardır.

\section{Ev içi iş Bölümü}

Aynı evde yaşamak gelin-kayınvalide ilişkisi üzerinde oldukça belirleyicidir. Çünkü ev içi sorumlulukların nasıl paylaşıldığı evin bu iki kadını için önemlidir. Ev işlerindeki paylaşım işin taşıdığı saygınlığa göre olmaktadır. Temizliğin belli tutum ve davranışları bir araya getirerek oluştuğunu ve içerdiği belirsizliklere rağmen saygınlığın bir parçası olarak hayati bir önem taşıdığını iddia eden Davidoff (2009) ev içinde hegemonik bir güce sahip olan farklı kadınlıklara, kadınlar arası tahakküm ilişkilerine işaret etmiştir. Kirli olandan ne kadar uzak olunduğu saygınlıkla ilişkilidir, tuvalet temizlemek bir saygınlık taşımazken evin düzenlenmesini içeren toz almak saygınlık içermektedir. Dolayısıyla evin temiz olması için üstlenilen işler kadınları farklılaştırmaktadır. Kayınvalideler, evin tüm işlerini, gelinin odasını temizlemeye kadar üstlenebilmektedir. Üçüncü gelinin "kendi odamı bile elleyemezdim" ifadesi, kayınvalidesinin yaptığı temizlikle gelini, evine yabancı kıldığının göstergesidir. Evin temizlenmesinin bir stratejik yanı gelinkayınvalide ilişkisinde kimin kötü olduğunu belirleyebilmesidir. Üçüncü gelinin anlatısına göre kayınvalidesi temizlik yaptırmadığı gelinini balkona oturtup oradan geçenlere "napıyim oturuyo" demektedir; çünkü evin temizliğinin, evin genç kadını, gelin tarafından sağlanması gerekmektedir (Özbay, 1982). Temizlik, çevredeki insanların önünde ve onların nezdinde gelin ve kayınvalidelerin itibar kazanma arzusunun olduğu bir mücadeleyi içermektedir (Sirman, 2010). Evin tüm temizliğini yapan özellikle dördüncü ve altıncı gelinler "hamarat, titiz" ifadeleriyle yüceltilmektedir. Hatta altıncı gelin evin temizlenmesiyle ilgili "köleliğe vardırana kadar yapıyodum" demektedir. Bunun yanı sıra altıncı gelin, kayınvalidesinin evin yöneticisi olduğunu, işleri onun yönlendirmesiyle yaptığını bildirmektedir. Yani, gelinin tüm ev işlerini üstlenmesi, evde gelinin konumunu güçlendirmemektedir. Dördüncü çiftte kayınvalide oğlunun evlenmesinden bu yana, pek çok ev içi sorumluluğundan el çekmiş görünmektedir ve "tez canlı" gelininin ev işlerini yürütmede iyi olması, iş paylaşımı nedeniyle olası çatışmaların önüne geçmektedir. Kaynak kullanımı ve kaynağın dışarıdan teminiyle doğrudan ilgili olan yemek pişirme, evdeki kadınlar arasındaki iktidar ilişkilerinin görünür olduğu bir ev işidir ve hatta ücretli ev hizmeti alsalar bile orta sınıf kadınların yemeği kendilerinin yaptıkları bilinmektedir (Bora, 2014). Kayınvalideler sadece saygınlık atfedilen yemek pişirme işini üstlenebilmekte ve bu işi özellikle evin ekonomisini belirlediği için paylaşmak istememektedir (YakaliCamoglu, 2007).

Bu çalışmada çatışmalı ilişkileri olan üçüncü gelin, aşağıda mutfağa giremediğini söylemektedir. Yemek pişiren kayınvalide mutfakta olarak evin ekonomisini yönetme hakkına sahiptir ve gelinine kendi parasını kontrol etme hakkı vermediği gibi evin ekonomisini geliniyle birlikte yönetmeye niyeti yoktur.

"Mutfağa giremiyodum ... alır eder yapar pazara çıkıyim anne bi öğreniyim yemek yapıyim gün yapardım arkadaşlarımın gün parasını bu alırdı sorardım hani niye ama bu evde yağı var fırını var elektriği var derdi (G3)" 
Mutfağı yöneten kadın, evin kadını hatta evin sahibi olmaktadır. Aşağıda altıncı kayınvalidenin mutfağın nasıl kullanılacağını belirleme hakkını gelinine vermediği görülmektedir, böylelikle evin kadını olmayı sürdürecektir ve mutfakta olmak, evi sahiplenmek demektir.

"Bulaşık makinesi var orda çürüyo elinde yıkıyo ama temiz yıkayamıyo ... anne makineye koyalım dediğin zaman yoo hayır ... olmaz işime karışma çok ağır sözler bu evin kadını ben miyim sen misin falan gibi şeyler ya çok kalp kırıcı... mutfakta işte anne ben yaparım dediğim zaman kızı çok iğrenç biridir evi iyice sahiplendi derdi benim için sanki benim evde gözüm varmış gibi (G6)"

Evdeki bu iki kadın arasındaki hiyerarşik iş bölümünde kayınvalideler mutfağı gelinlerine bırakarak mevcut konumlarını terk etmek istememektedir. Görüldüğü gibi evin temizliğinin kim tarafından yürütüleceği, - gelin-kayınvalide ilişkisinin dinamikleri içinde yapılan temizlikle ne elde edilmek istendiğine bağlıdır. Mesela, doğurganlık ve sağlık durumu gibi değişkenlere göre değişim göstermektedir (Özbay, 1982). Yaşlılık ya da hastalık sebebiyle gelinden bakım almak bu değişkenlerden biridir. Bakım alan kayınvalidelerin özledikleri arasında mutfaklar başı çekmektedir. Hatta altıncı kayınvalidenin "mutfağımı özledim" demesi gelinine ileri derecede bağımlı olmasına rağmen mutfağı hâlâ onunla paylaşmadığının göstergesidir.

Çocuk bakımı evin diğer kadınlarıyla paylaşılacak bir diğer ev içi iştir. Gelinden aileye çocuklar doğurması beklenmektedir ancak bu beklenti, gelinin doğurduğu çocukla kendi ailesini kurma ve kocasının ilgisini ailenin diğer üyelerinden çekme olasılığına gebedir. Bununla birlikte çocuk, kayınvalidenin bakım aracıı̆̆ıla gelin ve oğlunun ailesine dâhil olması için bir fırsattır. Çocuk bakımını üstlenmeleri yaşlıların egemenlik ilişkilerini sürdürmelerine aracı bir roldür. Nitekim çocuk bakımı konusunda gelinin tavsiye talep etmemesi ya da yapılan önerileri uygulamaması kayınvalidelerin gelinleriyle ilişkilerinde çatışma algılamasına sebep olmaktadır (Sandel, 2004). Gelinler de çatışmalarına bir sebep olarak çocuk bakımı hakkında kayınvalideleriyle ayrışmalarını bildirmişlerdir (Marotz-Baden ve Cowan, 1987). Bunlarla birlikte yaşlının çocuk bakımını üstlenmesi, minnet duygusuyla beraber gelininin gelecekte kendisine bakmasını sağlayacaktır (Guberman, 1999). Gelininin ailesinin dışında kalarak yalnızlaşma ihtimalinin yaşlıda yarattığı korku, çocuk bakımın üstlenilmesiyle ötelenmiş olmaktadır (Sirman, 2010) ve gelinin ailesiyle kendi ailesinin ilişkisinin sürmesi çocuk bakımıyla garanti altına alınmaktadır. Aynı evde yaşayan evin diğer tüm işlerini yürüten gelinler için çocuk bakımının yaşlı tarafından üstlenilmesi kolaylaştırıcı olabilmektedir. Görüşme sırasında hamile olan ikinci gelin, bebeği dünyaya geldiğinde kayınvalidesinden sağlığı el verdiği ölçüde çocuğuna bakım vermesini beklemektedir.

Aynı evde yaşamanın gelin-kayınvalide ilişkisine güçlü etkisi, gelinlerin "keşke ayrı evim olsaydı" cevaplarında görülmektedir. Kayınvalidesiyle ev işlerinin paylaşımı sebebiyle çatışmaya mahal vermeyecek kadar ev işlerinin tamamını yürüten dördüncü gelin, kendi evi olduğunda ev işlerini istediği zaman yürüterek yükünün azalacağını düşünmektedir. Aşağıda üçüncü gelin ayrı evde olmanın kayınvalideyle iletişimin kesileceği anlamını taşımadığı, kendi evinin kadını olmanın önemli olduğunu, düşlediği eylemlerle birlikte aktarmaktadır. Düşlediği eylemlerde dikkat çeken nokta gelinin kayınvalidesine hizmet etmeyi sürdürmesidir.

"Beraber oturmak asla istemezdim kapımı kendim açıyim çocuklarımla kendim ilgileniyim kayınvalidem yakında otursa ona gidiyim temizliğini yapıyim yemeğini yapıyim çayımızı içelim ondan sonra döniyim ben 
geliyim evime ... kendi evimin kadını olıyım isterdim bir evin içinde iki kadın istemezdim (G3)"

Aynı evde yaşanmaya devam edecek bu çiftlerde Rittenour ve Soliz'in (2009) ilişkisel niyet olarak değerlendirdiği gelecekte iletişimi sürdürme, bu çalışmanın katıımcıları için bir niyet değil, zorunluluktur. Bakım verme niyeti aynı evde yaşamaktan bağımsız değildir. Aslında gelinin niyetinin dışında aynı evde yaşamanın getirdiği bir sonuçtur. Bu sebeple dördüncü kayınvalide, gelinini kızından önemli gördüğünü ifade etmiştir, dördüncü gelin de kayınvalidesiyle paralel olarak aynı evde yaşadıkları için, aynı mahallede yaşayan kızını değil "evin içindeki gibi olmaz" diyerek kendisini bakımdan sorumlu tutmaktadır. Beşinci kayınvalide aynı evde yaşamadığı diğer gelinini "gelmese gelmez" diyerek bakımından sorumlu tutmamaktadır. Aynı evde yaşayan gelinler, birincil bakım veren olmak durumundadır.

\section{Bakımla Değişen Konumlar}

Bakım ilişkisiyle beraber gelin ve kayınvalidenin aile içindeki konumları değişmiştir, yeni edinilen bakım alan, bakım veren konumlarının kayınvalide ve gelin için sonuçları olmuştur. Yaşlanmanın etkisiyle birlikte, özellikle ev içinde değişen konumların gelin-kayınvalide ilişkisine yansımaları birinci gelinin "undan bana geçti otorite" ifadesinde görülmektedir. Kayınvalideler çoğunlukla geçmişte yapabildikleri ve artık yapamadıkları üzerinden kendilerini beşinci kayınvalidenin dile getirdiği gibi "işe yaramaz" olarak değerlendirmektedirler. Bu durumdan sıkıldıklarını ve hatta ölmek istediklerini bildirmişlerdir. Iç̧inde bulundukları konum, aldıkları bakımı kaybetme endişesi duymalarına sebep olmaktadır. Özellikle tam bağımlı olan kayınvalidelerin yaşamlarını sürdürebilmeleri, aldıkları bakıma bağlıdır. Görüşmeler sırasında kayınvalidelerde bu durumun yansımaları görülmüştür. Üçüncü kayınvalidenin "yaşlıyla fakirin derisi kalın olur" ve "gelin konuşuyo ben istediğim bu diyemiyorum yiyemiyorum bunlar hep değişti" ifadesi, birinci kayınvalidenin geliniyle ilişkisini "unu boşve gali" ifadesiyle konuşmak istemediğini belirtmesi bu durumun görüntüleridir.

$\mathrm{Bu}$ çalışmada kayınvalideler, gelinlerinin kendileri hakkında söylediklerinin tersine, iletişimlerinde gelinlerinin daha az uygunsuz davrandıklarını bildirmişlerdir. Sandel (2004) de yaşlı kayınvalidelerin gelinleriyle ilişkilerinde daha az şikâyet bildirdiklerini bulgulamıştır. Bakım alan kayınvalidelerin gelinleri hakkında daha az uygunsuz davranış bildirmeleri, hatta bazı kayınvalidelerin herhangi bir bildirimde dahi bulunmamaları, bakımı kaybetme endişesinin bir görünümü olabilir. Tam bağımlı üçüncü kayınvalide bakım alan konumunda eski konumuna ilişkin herhangi bir şey bulamadığını, her şeyin değiştiğini söylemektedir ve bu konum, gelinine istediğini deme ve gelininden istediklerini talep etme hakkını kendisinden almıştır. Üçüncü gelinin aşağıdaki ifadesinde, bakımla birlikte değişen konumların ve kayınvalidenin bakım gereksiniminin çatışmalı ilişkilerine nasıl yansıdığı görülmektedir.

"(Kayınvalidesi için) Sen bakmıcaksın bana bak evimde de oturuyosun bunları söylerdi ederdi anne yapma böyle ... durumu kötüleşmeye başladı sen bitanesin de bilmem nesin de (G3)"

Kayınvalidelerin bakım almanın yanı sıra yaşlanmanın getirdiği fiziksel, psikososyal değişimlerle baş etmeye çalıştıkları görülmüştür. Fiziksel değişimler sebebiyle geçmişte yapılanların mevcut fiziki koşulları sebebiyle artık yapılamaz oluşu, gözyaşlarıyla yâd edilmektedir. Tüm kayınvalideler mevcut şartlarıyla geçmişi kıyasladıklarında, sonuçtan memnuniyetsizdir. ileri yaşta olmaları sebebiyle yakınlarını, akranlarını kaybetmişler ve yalnızlık hissetmektedirler. Kendilerinin 
tercih etmedikleri sosyal alanlarındaki bu daralma, akranlarından sosyal destek alma ihtimallerini, özellikle yaşlılıkları ya da yatalak olmaları sebebiyle evden dışarı çıkamayan yaşlılar için ortadan kaldırmaktadır. Bu durum yaşlıları ihmal/istismar için riskli bir konumda tutmaktadır. Çünkü evlerinde kendilerinden sonraki iki kuşak vardır ve araştırma sırasında da gözlemlendiği üzere kuşakların yaşıyla etkileşimi sınırlıdır.

\section{Sonuç}

Hanehalkının biçimi (geniş, çekirdek, dağılmış aile), sosyoekonomik seviyesi ve sağlık koşulları bakım alan ve bakım verenlerin özerkliğini, bağımsızlığını ve yaşam kalitelerini belirleyen temel göstergelerdir (Arun ve Holdsworth, 2018). Hane içinde bir aile üyesinden bakım alan yaşıı ile bakım verenin özerkliğe, bağımsızlığa sahip olma(ma)sı ve sağlık koşullarının yeter(siz)liği yaşlı ihmal/ istismarı için önemli risk faktörleridir. Bu çalışmada kayınvalideler, ileri yaşta olma, bakım aldıkları gelinlerine bağımlı olma, kronik rahatsızlıklara ve bu rahatsızlıkların sonucu olarak fiziki engellere sahip olma gibi risk faktörlerini taşımaktadırlar. Gelinlerin kayınvalidelerini ihmal/istismar etmeye yönelten risk faktörleri arasında bakım veren rolünü benimsememeleri ya da zorunlu bakım vermeleri, başka bir alternatifin olmadığına dair inançlarının olması, bu inanç sebebiyle sosyal ya da kurumsal bakım desteği arayışında olmamaları gibi etkenler vardır. Ileri derecede bağımlı yaşlılara bakım veren gelinlerin sürekli biçimde evde olmaları, yaşlının artan bağımlılığı ve paylaşılmayan, tek başına üstlenilen diğer ev içi sorumlulukların bakım veren kadında evine, yaşlıya yetemediği hissini yaratması bakım yükünü artıran sebeplerdir (Alpteker, 2008; Arpacı, 2009) ve bakım yükü ile bakım stresi yaşlı ihmal/istismarı için ciddi bir risk faktörüdür.

Gelin ve kayınvalidenin içinde bulundukları ailenin dinamikleri, kültürel ve kurumsal nedenler gibi çevresel koşullar risk faktörleri taşıyabilmektedir. Söz konusu kadının bakım emeği olduğunda içerdiği cinsiyet ve yaş hiyerarşisiyle patriarkal toplumsal yapı, yaşlı ihmal/istismarının ortaya çıkması için ciddi bir risktir. Bu toplumsal yapının kurduğu ve disipline ettiği aile kurumunda kötü ve çatışmalı ilişkiler ve düşük sosyal desteğin olması(Johannesen ve LoGiudice, 2013) hem yaşlı hem bakım veren için risklidir. Destekleyici servislerin ulaşılabilir olmaması, resmî ya da gayri resmî sosyal destek ağlarının ve kurumların yetersizliği gibi kamusal yoksunluklar yaşlıyı ve bakım verenini istismar ve ihmal için riskli konuma itmektedir (Goodrich, 1997). Bu riskleri gözeten, bakım veren ve bakım alan arasında ötekine bağımlı olmakla gelişen hiyerarşik güç ilişkisinde tarafların özerklik, bağımsızlık kazanmasına imkân veren, yaşam kalitelerini artıran sosyal politikaların geliştirilmesi (Arun ve Holdsworth, 2018) yaşlı ihmal/istismarının önüne geçilmesinde elzemdir.

Tüm bu risklere rağmen, aslında her ilişki gibi karmaşık ve müzakereye hep açık olan gelinkayınvalide ilişkisinin varlığına yine karmaşık ve pek çok dinamiği içinde barındıran bakım ilişkisinin eklenmesi her zaman yaşlı ihmal/istismarılla sonuçlanmamaktadır. Bu çalışmada çatışmalı ya da çatışmasız gelinkayınvalide çiftlerinde tespit edilen koruyucu dinamikler şunlardır: Gelinlerin kendilerine atfettikleri olumlu kişilik özellikleri, gelinlerin kendi aileleri tarafından bakım için cesaretlendirilmeleri ve sosyal destek görmeleri, eşlerine duydukları sevgi, bakım yükü algılamamalarıdır.

Sonuç olarak her gelin-kayınvalide ilişkisi çatışmalı olmadığı gibi, çatışmalı her ilişki de ihmal/istismarı var kılmamaktadır. Bakımda yaşlı ihmal/istismarının gerçekleşmesi gelinkayınvalide ilişkisinin kendisine içkin olmaktan ziyade koruyucu dinamiklerin az, risk teşkil edenlerinse daha fazla olmasıyla ilişkilidir. 


\section{Kaynakça}

Alpteker, H. (2008). 65 yaş üstü bireylere evde bakım verenlerin yaşadığı güçlüklerin belirlenmesi. (Yayımlanmamış yüksek lisans tezi). Abant İzzet Baysal Üniversitesi Sağlık Bilimleri Enstitüsü, Bolu.

Arpacı, F. (2009). Yaşlıya bakan kadınların bakım yüklerinin incelenmesi. Yaşlı Sorunları Araştırma Dergisi, 1, 61-72.

Artan, T. (1996). Aile içi fiziksel yaşlı istismarı. (Yayımlanmamış yüksek lisans tezi.) İstanbul Üniversitesi Adli Tıp Enstitüsü, İstanbul.

Artan, T. (2013a). Türkiye'de Yaşlı İstismarına Genel Bir Bakış. Maltepe Üniversitesi Fen Edebiyat Fakültesi Dergisi, 2009(1-2), 38-62.

Artan, T. (2013b). Huzurevinde kalmakta olan yaşılıarda aile içi istismar. Toplum ve Sosyal Hizmet Dergisi, 24(2), 109-122.

Arun, Ö., ve Holdsworth, J.K. (2018). Generational Care and Support Mechanisms in Turkey: Identifying at Risk Populations. In Research on Family Structures in Turkey: Advanced Statistical Analysis, 2018. The General Directorate of Family and Social Services: Ankara.

Bilgili, N. (2000). Yaşlı bireye bakım veren ailelerin yaşadıkları sorunların belirlenmesi. (Yayımlanmamış Doktora Tezi). Hacettepe Üniversitesi Sağlık Bilimleri Enstitüsü, Ankara.

Bora, A. (2014). Kadınların Sınıfı. İstanbul: Illetişim Yayınları.

Brewer, L. (2001). Gender socialization and the cultural construction of elder caregivers. Journal of Aging Studies, 15(3), 217-235.

Davidoff, L. (2009). Feminist tarih yazımında sınıf ve cinsiyet (Çev. Ataşer, Z. ve Somuncuoğlu, S.) İstanbul: illetişim Yayınları.
Globerman, J. (1996). Motivations to care: Daughters-and sons-in-law caring for relatives with Alzheimer's disease. Family Relations, 37-45.

Goodrich, C. S. (1997). Results of a national survey of state protective services programs: Assessing risk and defining victim outcomes. Journal of Elder Abuse \& Neglect, 9(1), 69-86.

Gönüllü Taşkesen, C. (2012). Türkiye'de yaşlılık ve evde yaşlı bakımı: resmi karar ve uygulamaların yerinde tespiti (Isparta ili araştırması). (Yayımlanmamış yüksek lisans tezi). Süleyman Demirel Üniversitesi, Isparta.

Guberman, N. (1999). Daughters-in-law as caregivers: How and why do they come to care? Journal of Women \& Aging, 11(1), 85102.

Joffe, H ve Yardley, L. (2004). Contend and Thematic Analysis. Research Methods for Clinical and Health Psychology, (Ed. D. F. Marks and L. Yardley) içinde (56-68. ss.). London: Sage Publications.

Johannesen, M. ve LoGiudice, D. (2013). Elder abuse: A systematic review of risk factors in community-dwelling elders. Age and ageing, 42(3), 292-298.

Kandiyoti, D. (1988). Bargaining with Patriarchy. Gender and Society, 2(3), 274-290.

Keskinoğlu, P., Giray, H., Pıçakçıefe, M., Bilgiç, N. ve Uçku, R. (2004). Yaşlıda fiziksel, finansal örselenme ve ihmal edilme. Türk Geriatri Dergisi, 7(2), 57-61.

Kıssal, A. ve Beşer, A. (2009). Yaşıı istismar ve inmalinin değerlendirilmesi. TAF Preventive Medicine Bulletin, 8(4), 357-364. 
Louderback, P. (2000). Elder care: A positive approach to caregiving. Journal of the American Academy of Nurse Practitioners, 12(3), 97-100.

Marotz-Baden, R. ve Cowan, D. (1987). Mothers-in-law and daughters-in-law: The effects of proximity on conflict and stress. Family Relations, 385-390.

Özbay, F. (1982). Ev Kadınları. Ekonomik Yaklaşım, 3(1), 209-225.

Quinn, M. J., ve Tomita, S. K. (1997). Elder abuse and neglect: Causes, diagnosis, and interventional strategies. Springer Publishing Company.

Rittenour, C.veSoliz, C. (2009). Communicative and relational dimensions of shared family identity and relational intentions in motherin-law/daughter-in-law relationships: Developing a conceptual model for motherin-law/daughter-in-law research. Western Journal of Communication, 73(1), 67-90.

Sandel, T L. (2004). Narrated relationships: Mothers-in-law and daughters-in-law justifying conflicts in Taiwan's Chhanchng. Research on Language and Social Interaction, 37(3) 365-398.

Sirman, N. (2010). Köy Kadınının Aile ve Evlilikte Güçlenme Mücadelesi (Ed.), 1980'ler Türkiye'sinde Kadın Bakış Açısından Kadınlar içinde (221-247. ss.). İstanbul: İletişim Yayınları.

Soeda, A. ve Araki, C. (1999). Elder Abuse by Daughters-in-law in Japan. Journal of Elder Abuse \& Neglect, 11(1), 47-58.

Strasser, S. M. ve Fulmer, T. (2007). The Clinical Presentation of Elder Neglect: What We Know and What We Can Do? Journal of the American Psychiatric Nurses Association, 12, 340-349.

Thompson, L. (1991). Family Work: Women's Sense of Fairness." Journal of Family Issues, 12, 181-196.

Yakali-Camoglu, D. (2007). Turkish Family Narratives: The Relationships Between Mothers- and Daughters-in-law. Journal of Family History, 32(2), 161-178. 